DOI: $10.15193 / \mathrm{ZNTJ} / 2018 / 116 / 242$

PIOTR KOŁODZIEJCZYK, JAN MICHNIEWICZ

\title{
ZIARNO ZBÓŻ I PRODUKTY ZBOŻOWE JAKO ŹRÓDŁA BLONNIKA POKARMOWEGO
}

\begin{abstract}
Streszczenie
Na podstawie badań interdyscyplinarnych wykazano ścisły związek między poziomem spożycia błonnika pokarmowego a liczbą zachorowań na przewlekłe choroby niezakaźne. W pracy omówiono definicję błonnika pokarmowego oraz metody jego ilościowego oznaczania dostosowane do aktualnie obowiązującego pojęcia błonnika. Przedstawiono najnowsze dane dotyczące zalecanych dawek błonnika pokarmowego oraz wielkości spożycia błonnika i produktów, które zawierają ten składnik, przez przeciętnego Polaka. Dane GUS oraz najnowsza baza danych dotyczących zawartości składników odżywczych w 7999 artykułach żywnościowych, opracowana przez Departament Rolnictwa USA, potwierdzają, że w Polsce produkty zbożowe stanowią główne źródło błonnika. Wykazano, że w naszym kraju w 2016 r. dzienne spożycie błonnika pokarmowego wynosiło $15,4 \mathrm{~g}$ na 1 osobę, a produkty zbożowe dostarczały prawie $43 \%$ dobowej dawki tego składnika, z czego ponad 2/3 stanowiło pieczywo. Ponadto porównano zawartość błonnika pokarmowego w różnych rodzajach zbóż oraz w 1494 produktach zbożowych. Koszyk tych produktów obejmował wiele nowych dotychczas nieuwzględnianych w krajowej literaturze o tematyce żywieniowej, a obecnie coraz częściej spożywanych przez konsumentów w Polsce. $Z$ analizy tych danych wynika, że wszystkie produkty zbożowe nisko przetworzone, otrzymane $\mathrm{z}$ całych ziaren lub $\mathrm{z}$ ich dodatkiem oraz produkty pochodzące $\mathrm{z}$ zewnętrznych warstw ziarna są wielokrotnie bogatsze w błonnik pokarmowy niż produkty wysoko przetworzone i oczyszczone w procesie produkcyjnym.
\end{abstract}

Słowa kluczowe: błonnik pokarmowy, definicja, metody oznaczania, ziarno zbóż i produkty zbożowe, krajowe spożycie błonnika i produktów zbożowych

\section{Wprowadzenie}

W Polsce liczba chorych na przewlekłe choroby niezakaźne (Non-Communicable Diseases - NCDs), czyli tzw. choroby cywilizacyjne, stale utrzymuje się na wysokim poziomie $[23,28]$. Zalicza się do nich takie schorzenia, jak: otyłość, choroby sercowonaczyniowe (ChNS), cukrzycę i niektóre typy nowotworów. Z danych GUS i Narodo-

Mgr inż. P. Kołodziejczyk, prof. dr hab. J. Michniewicz, Instytut Technologii Żywności Pochodzenia Roślinnego, Wydz. Nauk o Żywności i Żywieniu, Uniwersytet Przyrodniczy w Poznaniu, ul. Wojska Polskiego 31,60-624 Poznań. Kontakt: jan.michniewicz@up.poznan.pl 
wego Instytutu Zdrowia Publicznego wynika, że ChNS i nowotwory są odpowiedzialne za $70 \%$ wszystkich zgonów, odpowiednio: 45,6 \% i 24,8 \% [23, 28]. Według danych GUS w ostatnich kilkunastu latach natężenie zgonów spowodowanych tymi chorobami nie zmieniło się istotnie [23]. Rozwojowi tzw. chorób XXI wieku sprzyjają przede wszystkim postęp współczesnej cywilizacji oraz czynniki związane z warunkami i stylem życia, na który składa się, obok niskiej aktywności fizycznej i palenia tytoniu, nieprawidłowa dieta obfitująca w tłuszcze zwierzęce, cukry proste i żywność wysoko przetworzoną, a uboga w produkty nisko przetworzone, bogate w błonnik pokarmowy (DF). Dlatego tak ważna jest edukacja w zakresie prawidłowego odżywiania i promocja produktów żywnościowych bogatych w ten składnik żywności. W Polsce opublikowano szereg prac przeglądowych poświęconych błonnikowi i jego funkcji w organizmie człowieka, ale tylko nieliczne w całości dotyczą produktów zbożowych, mimo że są one głównym źródłem tego składnika w codziennej diecie Polaków [2, 19]. Uznano zatem za celowe przygotowanie kompleksowego opracowania zawierającego aktualne dane dotyczące wielkości spożycia produktów zbożowych i błonnika pokarmowego w Polsce oraz jego zawartości w zróżnicowanej grupie tych produktów, obejmującej wiele nowych, coraz częściej spożywanych przez konsumentów, z uwzględnieniem aktualnej definicji błonnika, krytycznej oceny metod jego ilościowego oznaczania oraz roli w organizmie człowieka.

\section{Definicja błonnika pokarmowego}

Pojęcie „błonnik pokarmowy” (ang. dietary fibre, DF) jako pierwszy wprowadził Hipsley w 1953 r. [14], który zaobserwował, że ryzyko toksemii ciążowej występuje rzadziej u kobiet stosujących dietę bogatą w nieprzyswajalne węglowodany. Do początku lat 70. ubiegłego wieku w literaturze o tematyce żywieniowej spotyka się tylko nieliczne wzmianki o tym, że nieprzyswajalne węglowodany opóźniają proces trawienia oraz ułatwiają wypróżnianie. Wówczas ten składnik żywności był określany i ilościowo oznaczany jako błonnik surowy (ang. crude fibre, CF). Dopiero w 1972 r. termin ten został bliżej zdefiniowany przez Trowella [26]. Zgodnie z zaproponowaną definicją „błonnik pokarmowy to pozostałość ścian komórkowych produktów roślinnych, która nie ulega hydrolizie pod wpływem enzymów trawiennych w przewodzie pokarmowym człowieka". Definicja ta została przyjęta i powszechnie funkcjonowała aż do końca pierwszej dekady XXI wieku. W 2008 roku Europejski Urząd ds. Bezpieczeństwa Żywności (EFSA) wraz z Komisją Kodeksu Żywnościowego (CAC) zaproponowali nową definicję błonnika pokarmowego, która została zaakceptowana przez Komisję Europejską [14]. Aktualnie obowiązująca definicja składa się z trzech części: określenia ogólnego błonnika, części opisującej możliwe jego składniki w zależności od źródła ich pochodzenia oraz części dotyczącej oddziaływania fizjologicznego danego składnika. Zgodnie z tą definicją błonnik pokarmowy to mieszanina sacharydów 
o stopniu polimeryzacji większym niż trzy, które nie są trawione i wchłaniane w jelicie cienkim człowieka. Polimery sacharydów należą do następujących grup: jadalne, naturalnie występujące w żywności gotowej do spożycia, otrzymane z surowców roślinnych przy użyciu metod fizycznych, enzymatycznych lub chemicznych, których korzystne efekty fizjologiczne zostały naukowo udowodnione oraz syntetyczne, których korzystne efekty na organizm człowieka zostały również naukowo udokumentowane przez kompetentne autorytety. Obok polimerów sacharydów do DF zalicza się ligninę oraz inne składniki towarzyszące im w ścianach komórkowych produktów roślinnych, które są ilościowo oznaczane za pomocą powszechnie obowiązujących metod. Do tych składników zalicza się: związki fenolowe, fityniany, woski, saponiny, fitosterole, kutynę itd., a także białka oporne na działanie enzymów trawiennych oraz różne rodzaje skrobi opornej (RS) [14, 25].

\section{Metody oznaczania błonnika pokarmowego}

Różnorodność składników DF sprawia, że zarówno w badaniach naukowych, jak i w przemysłowych laboratoriach kontroli jakości żywności stosuje się różne metody jego ilościowego oznaczania. W wielu przypadkach porównywanie wyników oznaczeń między nimi jest nieuprawnione metodologicznie. W 2011 r. Komitet ds. Metod Analitycznych i Pobierania Próbek CAC (CCMAS) określił listę metod oznaczania DF, zmodyfikowaną w 2014 r., i wydał dokument o charakterze przewodnika (Codex Procedural Manual) [5, 30]. W dokumencie tym wymienia się 4 rodzaje metod (tab. 1). Pierwszy rodzaj obejmuje grupę 9 metod ogólnych. Sześć z nich pozwala na ilościowe oznaczanie tylko frakcji wysokocząsteczkowych (HMW) polisacharydów $>9$ monomerów, a trzy zarówno frakcji HMW, jak i frakcji niskocząsteczkowych (LMW) $\leq 9$ monomerów. Drugi rodzaj zawiera grupę pięciu metod „referencyjnych”, a trzeci jedną metodę „alternatywną” formalnie zatwierdzoną. Metody należące do drugiego i trzeciego rodzaju umożliwiają ilościowe oznaczanie specyficznych składników DF w pełnym zakresie liczby jednostek monomerów. Oznaczona ilość DF przy użyciu metod należących do pierwszego rodzaju jest determinowana rodzajem przyjętej procedury. Z kolei metody drugiego rodzaju pozwalają na rozstrzyganie sporów między stronami, dotyczących rzeczywistego poziomu składników DF, natomiast nie można ich rozwiązać za pomocą metody trzeciego rodzaju. Ostatni, czwarty rodzaj, obejmuje grupę pięciu metod. Są to metody „niewiążące”, które można zaliczyć do każdego z trzech wyżej wymienionych rodzajów. Tej grupy metod nie zweryfikowano jednak w badaniach międzylaboratoryjnych zgodnych z międzynarodowymi wytycznymi, co nie pozwala na ich formalne zatwierdzenie [30]. 


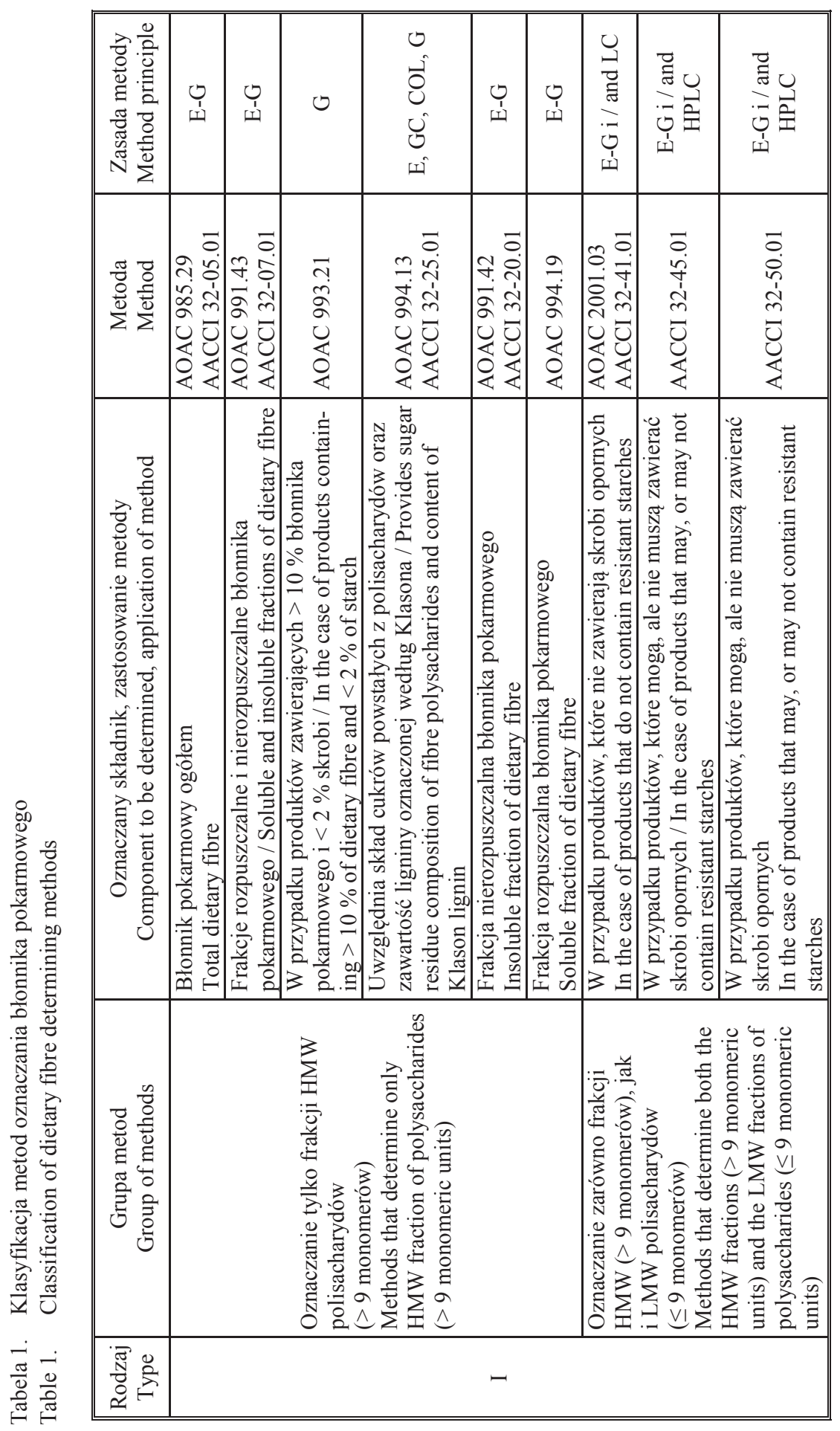




\begin{tabular}{|c|c|c|c|c|c|c|c|c|c|}
\hline 피 & 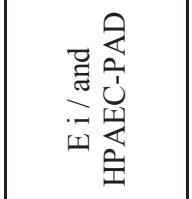 & 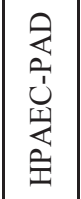 & 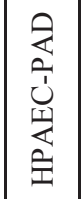 & 피 & 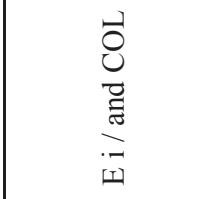 & 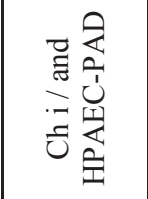 & 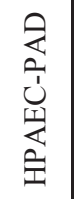 & 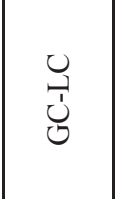 & 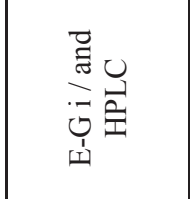 \\
\hline 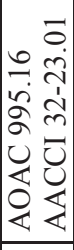 & 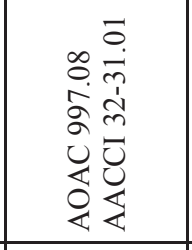 & 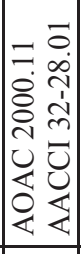 & 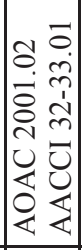 & 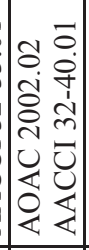 & 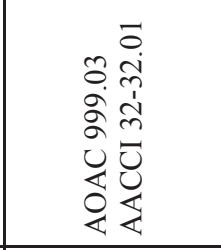 & 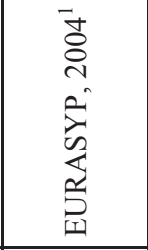 & 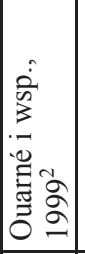 & 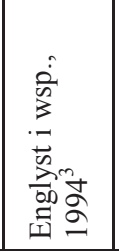 & 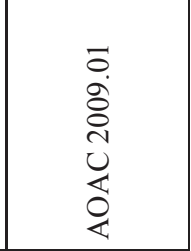 \\
\hline 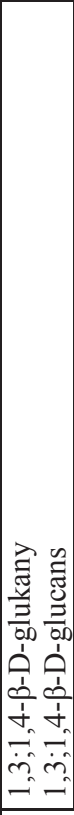 & 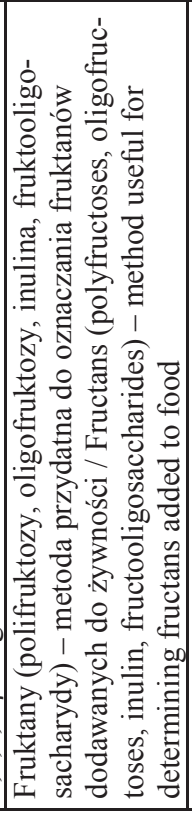 & 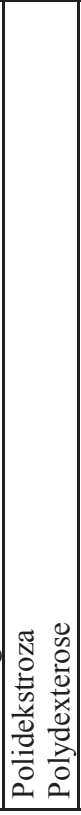 & 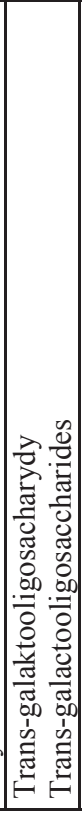 & 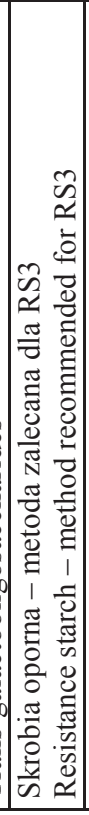 & 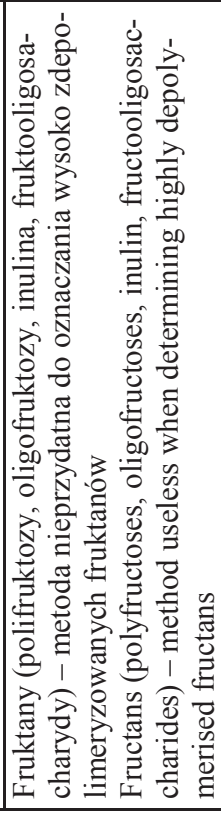 & 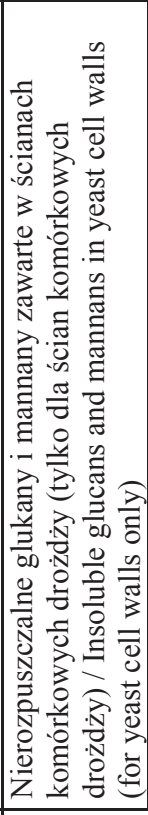 & 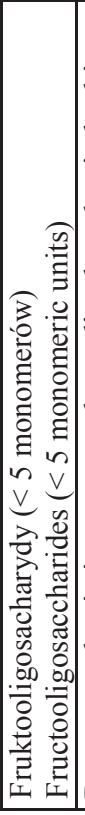 & 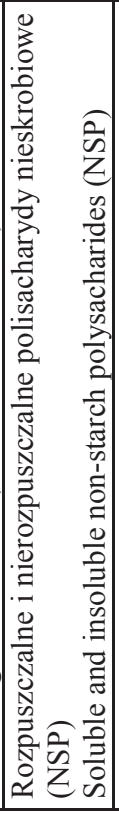 & 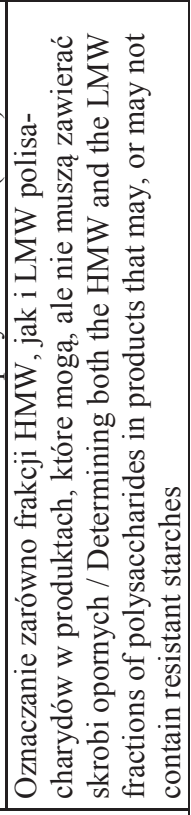 \\
\hline \multicolumn{6}{|c|}{ 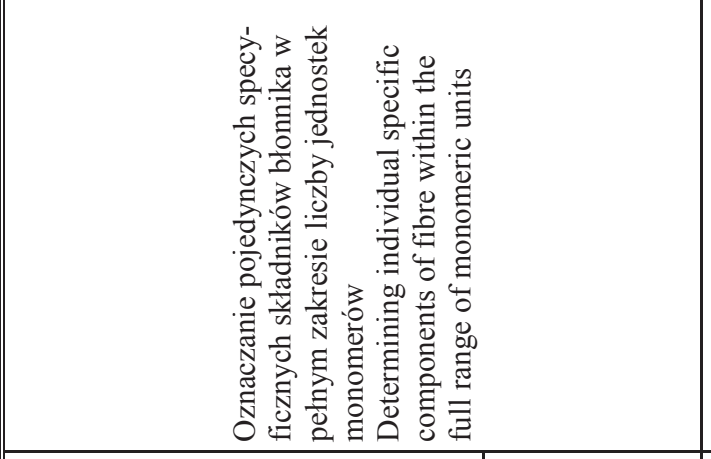 } & \multicolumn{4}{|c|}{ 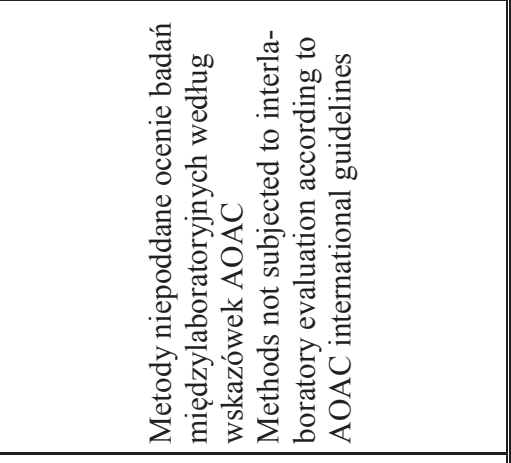 } \\
\hline \multicolumn{5}{|c|}{$=$} & $\Xi$ & \multicolumn{4}{|c|}{$z$} \\
\hline
\end{tabular}




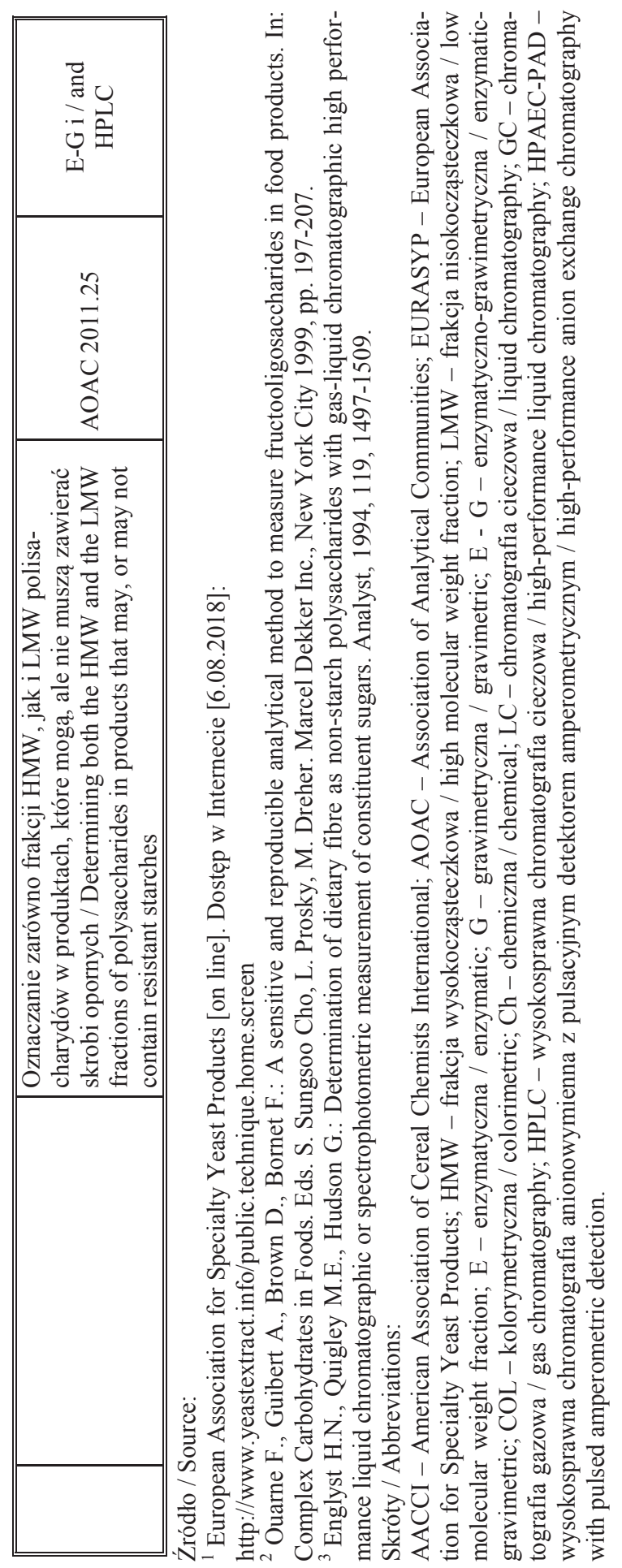


Najszersze zastosowanie w oznaczaniu zawartości DF w ziarnie zbóż i jego produktach znalazły klasyczne metody enzymatyczno-grawimetryczne AACCI 32-05.01 (AOAC 985.29) oraz AACCI 32-07.01 (AOAC 991.43). Obie należą do pierwszego rodzaju metod i pozwalają na oznaczanie tylko polisacharydów HMW wraz z niektórymi rodzajami RS. Pierwsza z metod umożliwia oznaczanie ilości DF ogółem (TDF), natomiast $\mathrm{W}$ drugiej oznaczenie przebiega $\mathrm{z}$ podziałem na frakcje nierozpuszczalną błonnika (IDF) i rozpuszczalną (SDF) wytrącaną w 78-procentowym etanolu. Metody te nie pozwalają natomiast na ilościowe oznaczenie części opornych na trawienie maltodekstryn, fruktanów, arabinogalaktanów i pektyn oraz całkowitej ilości ligniny i niektórych typów RS oraz rozpuszczalnych frakcji LMW, takich jak: galakto- fruktomalto-, arabinoksylo- i ksylooligosacharydy. Ilości TDF, jak i frakcji IDF oraz SDF, w ziarnie zbóż i ich produktach oznaczone tymi metodami są z reguły niedoszacowane. $\mathrm{Z}$ tego powodu w praktyce stosuje się metody, które stanowią kombinację metod grawimetrycznych, enzymatyczno-grawimetrycznych, chromatograficznych czy enzymatycznych $\mathrm{w}$ fuzji $\mathrm{z}$ detekcją kolorymetryczną. Przykładem takich kombinacji jest sprzęgnięcie grawimetrycznej metody Klasona oznaczania zawartości ligniny z metodą chromatografii gazowej i kolorymetryczną metodą oznaczania cukrów prostych powstałych z polisacharydów nieskrobiowych (NSP). Kolejnym przykładem są takie, które łączą metody oznaczania NSP z enzymatyczno-spektrofotometrycznymi lub enzymatyczno-chromatograficznymi metodami oznaczania różnych typów RS [30]. Fuzje tych metod stwarzają jednak niebezpieczeństwo przeszacowania zawartości DF w badanych produktach, ponieważ trudno jest określić, jaką część ogólnej ilości badanego składnika stanowi frakcja HMW, a jaką frakcja LMW. Metodami najbardziej uniwersalnymi i wiarygodnymi, które w pełni uwzględniają różnorodność składników DF, są dwie niedawno opracowane metody: AACCI 32-45.01 i AACCI 32-50.01. Należą one do pierwszego rodzaju i są określane mianem metod enzymatyczno-grawimetrycznych z zastosowaniem wysokosprawnej chromatografii cieczowej (HPLC) [30]. Obie metody umożliwiają oznaczenie wszystkich składników DF, w pełnym zakresie liczby jednostek monomerów, bez ryzyka ich podwójnego liczenia. W Polsce, przed 20 laty, opracowano normę ilościowego oznaczenia DF, która funkcjonuje do dzisiaj. Aktualnie jest ona niedostosowana do obecnie obowiązującej definicji tego składnika żywności [20]. Wyniki oznaczeń DF przy użyciu tej metody są trudne do porównania z wyżej opisanymi metodami. $Z$ jednej strony są one przeszacowane, ponieważ obowiązująca procedura nie uwzględnia poziomu zawartości niestrawionego białka w błonniku, z drugiej natomiast zaniżone, gdyż wynik końcowy oznaczenia nie obejmuje frakcji LMW sacharydów oraz różnych rodzajów RS. 


\section{Rola błonnika pokarmowego $\mathrm{w}$ profilaktyce i wspomaganiu leczenia przewlekłych chorób niezakaźnych (NCDs)}

Już w II wieku n.e. zaobserwowano, że biały chleb blokuje jelita i spowalnia pasaż treści pokarmowej, natomiast ciemny chleb jest dobry dla zdrowia jelit [14]. Przez 18 stuleci nie przywiązywano wagi do roli DF w żywieniu człowieka i dopiero na przełomie lat 60. i 70. XX w. brytyjscy lekarze zaobserwowali, że u rdzennych mieszkańców Afryki rzadko występują choroby, które rozprzestrzeniają się w krajach Europy Zachodniej i USA. W ich opinii różnice te były powodowane różnym stopniem oczyszczenia składników codziennej diety mieszkańców Afryki i Europy. W konkluzji swoich badań stwierdzili, że polisacharydy niestrawione w przewodzie pokarmowym mogą zapobiegać niektórym przewlekłym chorobom cywilizacyjnym [4]. Od tego czasu podjęto liczne wielokierunkowe badania nad wpływem DF zbóż na zdrowie człowieka, które stopniowo potwierdzały tezę sformułowaną przed 50 laty. Już pod koniec ubiegłego stulecia wykazano, w badaniach prowadzonych na grupie 38470 kobiet w wieku $55 \div 69$ lat, że konsumpcja 1 porcji całoziarnowych produktów zbożowych dziennie w istotny sposób przyczynia się do wydłużenia życia [13]. W krajach rozwiniętych, jak i w Polsce, jedną z najczęściej występujących przyczyn zgonów są choroby sercowo-naczyniowe $[23,28]$. W celu weryfikacji istotnego wpływu wielkości spożycia błonnika na ryzyko zachorowania na ChNS przeprowadzono wiele badań klinicznych i epidemiologicznych. Slavin [24] przytacza badania grupy 21930 fińskich mężczyzn w wieku $50 \div 69$ lat, w których wykazano ścisły związek między ryzykiem zapadnięcia na ChNS a poziomem spożycia wysokobłonnikowych produktów zbożowych. Z kolei w USA w badaniach populacji liczącej 43757 pracowników służby zdrowia w wieku $40 \div 75$ lat udokumentowano, że błonnik zbożowy istotnie obniża ryzyko zawału serca, które maleje wraz ze zwiększaniem porcji tego składnika pochodzącej z produktów całoziarnowych o każde $10 \mathrm{~g}$ [22]. Jedną z głównych przyczyn zachorowalności na ChNS jest nieprawidłowa gospodarka lipidowa człowieka, a zwłaszcza wysoki poziom cholesterolu ogółem i nieodpowiedni stosunek lipoprotein o wysokiej gęstości (HDL) do lipoprotein o niskiej gęstości (LDL). W wielu badaniach klinicznych udowodniono, że duży udział produktów zbożowych w diecie przyczynia się do istotnego obniżenia poziomu cholesterolu ogółem we krwi oraz poprawy wartości stosunku HDL do LDL [24, 25]. Jedna z wielu hipotez zakłada, że niestrawione w jelicie cienkim NSP docierając do okrężnicy, ulegają częściowej lub pełnej fermentacji do krótkołańcuchowych kwasów tłuszczowych: octowego, propionowego i masłowego, które w skomplikowanych, nie do końca wyjaśnionych procesach metabolicznych oddziałują na gospodarkę lipidową człowieka [24, 25, 29]. Ponadto kwasy te obniżają pH w okrężnicy oraz zmniejszają ryzyko powstawania polipów i zachorowania na raka jelita grubego, jak również wpływają na ogólną poprawę stanu zdrowia jelit [29]. McIntosch i wsp. [18] porównali wpływ diety bogatej w wysokobłonnikowe pro- 
dukty pszenne oraz żytnie i wykazali, że 4-tygodniowa interwencja żywieniowa powoduje zwiększenie masy kału o $1 / 3$ i obniżenie w nim poziomu $\beta$-glukuronidazy oraz podwyższenie ilości kwasu masłowego i maślanów. Udokumentowano także wpływ produktów całoziarnowych na obniżenie masy ciała osób otyłych oraz zwiększenie uczucia sytości $[24,25]$. Wysokobłonnikowe produkty zbożowe spowalniają trawienie pokarmu, co sprawia, że oddziałują również na poziom glikemii i insulinemii poposiłkowej [24]. Charakteryzują się one istotnie niższym indeksem glikemicznym, zwłaszcza produkty jęczmienne i owsiane bogate $\mathrm{w} \beta$-glukany, w porównaniu $\mathrm{z}$ wysoko oczyszczonymi produktami, np. jasnym pieczywem pszennym [24]. W badaniach klinicznych udowodniono, że spożywanie produktów całoziarnowych istotnie redukuje ryzyko gwałtownego wzrostu stężenia glukozy we krwi oraz wyrzutu insuliny [15, 24, 25]. W badaniach epidemiologicznych przeprowadzonych na grupie 90000 kobiet i 45000 mężczyzn udowodniono, że konsumpcja całoziarnowych produktów zmniejsza o $30 \%$ ryzyko zachorowania na cukrzycę typu $2 \mathrm{w}$ porównaniu z osobami niestosującymi diety bogatej w DF [24]. Reasumując, należy stwierdzić, że wszystkie badania epidemiologiczne i kliniczne potwierdzają tezę, że istnieje ścisły związek między wielkością spożycia produktów zbożowych bogatych w DF a poziomem zachorowań na przewlekłe choroby niezakaźne, jak i ogólnym stanem zdrowia społeczeństw w bogatych, wysoko rozwiniętych krajach.

\section{Zalecane dawki błonnika pokarmowego a jego spożycie}

Na podstawie dotychczasowej wiedzy na temat wpływu DF na zdrowie człowieka lekarze i eksperci żywieniowi opracowali zalecenia dotyczące minimalnej dawki dziennego spożycia tego składnika żywności. W różnych krajach wielkość ta waha się w przedziale $18 \div 38 \mathrm{~g}$ /dzień dla osoby dorosłej [14]. Według zaleceń FAO, WHO oraz EFSA i Amerykańskiej Agencji Żywności i Leków (US FDA), rekomendowana wielkość spożycia DF wynosi $25 \mathrm{~g}$ /dzień $[6,14]$. Jednocześnie wielkość tej dawki określa się w przeliczeniu na jednostkę dostarczanej energii. Zgodnie z rekomendacjami EFSA i FDA codzienna dawka DF powinna kształtować się na poziomie co najmniej $3 \mathrm{~g}$ na $1 \mathrm{MJ}$ energii zawartej w diecie [6]. W Polsce zalecenia spożycia tego składnika nie są jeszcze precyzyjnie określone, ale sugeruje się dawkę DF na poziomie $20 \div 40 \mathrm{~g}$, wskazując jednocześnie, że większe ilości są bardziej pożądane [19]. Analiza wielkości dziennego spożycia DF w sześciu najbardziej rozwiniętych gospodarczo krajach świata (we Francji, Japonii, Niemczech, Wielkiej Brytanii, Włoszech i USA) wskazuje, że zawiera się ona w granicach od $12 \mathrm{~g}$ dla kobiet w USA do $24 \mathrm{~g}$ dla mężczyzn w Niemczech [14]. W większości tych krajów wielkości te istotnie odbiegają od zalecanych norm. Na przykład w USA średnie spożycie DF kształtuje się na poziomie 15 g/dzień [14]. Spożycie DF w Polsce jest również mniejsze niż dawka zalecana przez EFSA [17]. Według obliczeń Laskowskiego [16] średnia ilość DF, która znajdowała 
się w codziennej diecie Polaka w 2011 r., wynosiła 19 g, przy medianie 17 g. Bardziej optymistyczne dane podają Górecka i wsp. [9], którzy na podstawie podobnych danych wykazali, że przeciętne spożycie DF w latach $2000 \div 2009$ wynosiło $27,8 \mathrm{~g} /$ dzień i wskazali na wyraźną tendencję malejącą tej wielkości od 29,5 g w 2000 r. do $25,4 \mathrm{~g}$ w 2009 r. W Polsce, obok niekorzystnej malejącej tendencji spożycia DF, również wiedza na temat tego składnika żywności oraz jego wpływu na organizm człowieka jest niezadowalająca. Potwierdzają to m.in. badania przeprowadzone w 2016 r. na 206osobowej grupie studentów warszawskich uczelni medycznych i pozamedycznych [15].

\section{Ziarno zbóż i jego produkty jako źródła błonnika pokarmowego}

W większości krajów świata, w tym w Polsce, głównym źródłem DF w codziennej diecie są przetwory zbożowe, a zwłaszcza pieczywo. Z danych statystycznych dotyczących wielkości spożycia produktów żywnościowych, które zawierają DF, wynika, że w 2016 r. przeciętny Polak spożył 231 kg produktów pochodzenia roślinnego, czyli $630 \mathrm{~g} /$ dzień (tab. 2) [23]. W obliczeniach tych uwzględniono roczne spożycie produktów żywnościowych będących źródłem DF, które sklasyfikowano w siedmiu grupach: produkty zbożowe ogółem, produkty zbożowe z podziałem na pieczywo i inne przetwory zbożowe, nasiona roślin strączkowych, owoce, warzywa, ziemniaki oraz soki owocowo-warzywne. Podana wielkość spożycia pieczywa jest zaniżona, gdyż ze względu na brak wiarygodnych danych statystycznych w bilansie tym nie uwzględniono pieczywa chrupkiego, tostowego i cukierniczego. Z tabeli tej wynika, że dominującymi ilościowo składnikami tego segmentu żywności w diecie Polaków są produkty zbożowe i warzywa. Ich udział w spożyciu całego wolumenu produktów, które zawierają DF jest zbliżony (30,7 i 26,7 \%) i wraz z ziemniakami wynosi $76 \%$.

Podaż DF w codziennej diecie jest wypadkową poziomu tego składnika w poszczególnych produktach żywnościowych wchodzących w jej skład oraz wielkości udziału tych produktów w diecie. Ilość DF w dziennej racji pokarmowej przeciętnego Polaka w 2016 r. oszacowano na podstawie zawartości składników odżywczych w produktach żywnościowych ujętych w bazie danych SR 28 z 2018 r., opracowanej przez Departament Rolnictwa USA [27] oraz wielkości dobowego spożycia poszczególnych produktów na osobę [23]. W pierwszym kroku z bazy obejmującej 7999 produktów żywnościowych wyselekcjonowano 4612, które zawierają DF. Z tej liczby wybrano 2966 produktów lub ich odpowiedników, które spożywa się w Polsce. Każdy z nich przypisano do jednej z siedmiu ww. grup żywności, a następnie oszacowano średnią zawartość DF w poszczególnych produktach tworzących pojedynczą grupę. W ostatnim kroku na podstawie średnich zawartości tego składnika w produktach oraz ich udziału w wielkości spożycia obliczono wartości średnich ważonych zawartości DF 
Tabela 2. Krajowa wielkość spożycia produktów żywnościowych zawierających błonnik pokarmowy oraz spożycie błonnika na 1 osobę w gospodarstwach domowych według danych GUS z 2016 r. oraz bazy SR 28 składników odżywczych opracowanej przez Departament Rolnictwa USA (USDA)

Table 2. Consumption of food products containing dietary fibre and its intake per capita in households in Poland according to GUS data of 2016 and to USDA National Nutrient Database SR 28

\begin{tabular}{|c|c|c|c|c|c|}
\hline \multirow[t]{2}{*}{$\begin{array}{l}\text { Produkty żywnościowe } \\
\text { Food products }\end{array}$} & \multirow{2}{*}{$\begin{array}{c}\text { Roczne } \\
\text { spożycie } \\
\text { [kg/osobę] } \\
\text { Annual } \\
\text { consumption } \\
\text { [kg per capita] }\end{array}$} & \multicolumn{2}{|c|}{$\begin{array}{c}\text { Dzienne spożycie } \\
\text { [g/osobę] } \\
\text { Daily consumption } \\
\text { [g per capita] }\end{array}$} & \multicolumn{2}{|c|}{$\begin{array}{l}\text { Udział procentowy } \\
\text { w ogólnej ilości } \\
\text { Percentage of total } \\
\text { amount }[\%]\end{array}$} \\
\hline & & $\begin{array}{l}\text { produkt } \\
\text { product }\end{array}$ & $\begin{array}{l}\text { błonnik } \\
\text { fibre }\end{array}$ & $\begin{array}{l}\text { produkt } \\
\text { product }\end{array}$ & $\begin{array}{c}\text { błonnik } \\
\text { fibre }\end{array}$ \\
\hline $\begin{array}{l}\text { Produkty zbożowe ogółem, w tym: } \\
\text { Total cereal products, including: }\end{array}$ & 71 & 194 & 6,6 & 30,7 & 42,7 \\
\hline - pieczywo* / bread* & 43 & 116 & 4,6 & 18,4 & 30,0 \\
\hline - inne produkty / other products & 28 & 78 & 2,0 & 12,3 & 12,7 \\
\hline Strączkowe / Legumes & 1 & 2 & 0,1 & 0,3 & 0,9 \\
\hline Owoce / Fruits & 44 & 120 & 3,1 & 19,1 & 20,3 \\
\hline Warzywa / Vegetables & 61 & 168 & 3,4 & 26,7 & 21,8 \\
\hline Ziemniaki / Potatoes & 42 & 114 & 2,1 & 18,2 & 13,4 \\
\hline $\begin{array}{l}\text { Soki owocowo-warzywne } \\
\text { Fruit and vegetable juices }\end{array}$ & 12 & 32 & 0,2 & 5,1 & 1,0 \\
\hline Razem produkty / Products in total & 231 & 630 & 15,4 & 100 & 100 \\
\hline
\end{tabular}

Objaśnienia / Explanatory notes:

* - z wyłączeniem pieczywa chrupkiego, tostowego i cukierniczego (brak danych) / excluding crispbread, toasted breads, and pastry (no data)

Źródło / Source: opracowanie własne na podstawie [23, 27] / the author's own study based on [23, 27]

w poszczególnych grupach. Do obliczeń przyjęto, że średnia zawartość DF w g na $100 \mathrm{~g}$ produktu wynosi: pieczywo $-4,0 \mathrm{~g}(\mathrm{n}=64)$, inne produkty zbożowe $-2,5 \mathrm{~g}$ $(\mathrm{n}=1430)$, strączkowe $-7,0 \mathrm{~g}(\mathrm{n}=356)$, owoce $-2,6 \mathrm{~g}(\mathrm{n}=278)$, warzywa $-2,0 \mathrm{~g}$ $(\mathrm{n}=726)$, ziemniaki $-1,8 \mathrm{~g}(\mathrm{n}=66)$ i soki owocowe $-0,5 \mathrm{~g}(\mathrm{n}=46)$. Taka metoda obliczeń wydaje się być uprawniona, ponieważ, mimo istotnych różnic między asortymentem produktów żywnościowych znajdujących się na rynkach USA i Polski oraz różnic między zwyczajami i tradycjami żywieniowymi, duży segment produktów wytwarzanych przez międzynarodowe koncerny znajduje się zarówno na tamtejszym, jak i krajowym rynku. Ponadto część z nich jest importowana, zarówno do USA, jak i do Polski, i zawiera identyczną lub zbliżoną ilość DF. Dodatkową zaletą przyjętego sposobu jest czerpanie danych pochodzących tylko z jednego zasobu danych, a nie $\mathrm{z}$ wielu różnych źródeł, często trudnych do porównania. Na podstawie analizy danych zawartych w tab. 2. potwierdzono, że pieczywo i inne produkty zbożowe są głównym źródłem DF w diecie Polaków. Dostarczają one 43 \% dziennej dawki DF, z czego ponad 
$2 / 3$ stanowi pieczywo, podczas gdy warzywa wraz ziemniakami $-35 \%$, natomiast owoce $-20 \%$. Udział nasion strączkowych i soków w dziennej podaży DF jest marginalny i kształtuje się na poziomie $2 \%$. Z analizy tej wynika, że w Polsce w 2016 r. dzienne spożycie DF wynosiło $15,4 \mathrm{~g}$ na 1 osobę. Wynik ten jest zbliżony do tego, który podaje Laskowski [16] i o ok. 60 \% niższy niż ten, który obliczyli Górecka i wsp. [9].

W tab. 3. podano zawartość DF w ziarnie różnych rodzajów zbóż chlebowych i niechlebowych oraz w orzeszkach gryki w g na 100 g ziarna [27]. Dane te, pobrane z bazy danych SR 28, pozwalają na podział zbóż pod względem zawartości DF w ziarnie na trzy grupy. Pierwsza obejmuje żyto, pszenżyto i pszenicę zwyczajną o zawartości DF $12 \div 16 \mathrm{~g} / 100 \mathrm{~g}$.

Tabela 3. Zawartość błonnika pokarmowego w ziarnie zbóż [g/100 g]

Table 3. Content of dietary fibre in cereal grains [g/100 g]

\begin{tabular}{|l|c|l|c|}
\hline \multicolumn{1}{|c|}{ Ziarno zbóż / Cereal grains } & $\begin{array}{c}\text { Błonnik } \\
\text { Dietary fibre }\end{array}$ & \multicolumn{1}{|c||}{ Ziarno zbóż / Cereal grains } & $\begin{array}{c}\text { Błonnik } \\
\text { Dietary fibre }\end{array}$ \\
\hline $\begin{array}{l}\text { Pszenica twarda czerwona/biała } \\
\text { Hard red/white wheat }\end{array}$ & $12,2 / 12,2$ & $\begin{array}{l}\text { Pszenżyto } \\
\text { Triticale }\end{array}$ & 14,6 \\
\hline $\begin{array}{l}\text { Pszenica miękka czerwona/biała } \\
\text { Soft red/white wheat }\end{array}$ & $12,5 / 12,7$ & $\begin{array}{l}\text { Ryż brązowy (długi/średni) } \\
\text { Rice brown (long/medium) }\end{array}$ & $3,4 / 3,6$ \\
\hline Żyto / Rye & 15,1 & Ryż biały / Rice white & 2,8 \\
\hline $\begin{array}{l}\text { Jęczmień obłuszczony } \\
\text { Pearled barley }\end{array}$ & 10,1 & $\begin{array}{l}\text { Ryż dziki } \\
\text { Rice wild }\end{array}$ & 6,2 \\
\hline $\begin{array}{l}\text { Owies obłuszczony } \\
\text { Pearled oats }\end{array}$ & 10,2 & $\begin{array}{l}\text { Sorgo } \\
\text { Sorghum }\end{array}$ & 6,8 \\
\hline $\begin{array}{l}\text { Kukurydza żółta/biała } \\
\text { Sweet yellow/white corn }\end{array}$ & $10,6 / 10,6$ & $\begin{array}{l}\text { Proso } \\
\text { Millet }\end{array}$ \\
\hline Kukurydza niebieska / Corn blue & 7,3 & Gryka / Buckwheat & 10,0 \\
\hline
\end{tabular}

Źródło / Source:

opracowanie własne na podstawie [27] / the author's own study based on [27]

Te trzy rodzaje zbóż są powszechnie uprawiane w Polsce i stanowią ok. 60 \% krajowej produkcji ogółem [23]. Druga grupa to obłuszczone ziarno jęczmienia i owsa oraz proso i różne gatunki kukurydzy, które zawierają $7 \div 12 \mathrm{~g} \mathrm{DF} \mathrm{w} 100 \mathrm{~g}$ oraz trzecia, która obejmuje różne gatunki ryżu i sorgo o zawartości DF $2 \div 7 \mathrm{~g} / 100 \mathrm{~g}$. Ilości tego składnika w jęczmieniu i owsie podano w ziarnie odplewionym i obłuszczonym, ponieważ w przetwórstwie tych zbóż tylko takie ziarno jest surowcem do produkcji wyrobów jęczmiennych i owsianych, np. całego ziarna, kasz, płatków czy otrąb owsianych. Oddzielnie potraktowano grykę, ponieważ nie należy ona do rodziny traw, a do rodziny rdestowatych. W tab. 4. zestawiono zawartość DF w grupie 1494 produktów 
Tabela 4. Zawartość błonnika pokarmowego w wybranych produktach zbożowych [g/100 g produktu]

Table 4. Content of dietary fibre in some cereal products [g/100 g of product]

\begin{tabular}{|c|c|c|c|}
\hline $\begin{array}{l}\text { Produkty zbożowe } \\
\text { Cereal products }\end{array}$ & $\begin{array}{c}\text { Zawartość } \\
\text { błonnika } \\
\text { Content of } \\
\text { dietary fibre }\end{array}$ & $\begin{array}{l}\text { Produkty zbożowe } \\
\text { Cereal products }\end{array}$ & $\begin{array}{l}\text { Zawartość błon- } \\
\text { nika } \\
\text { Content of dieta- } \\
\text { ry fibre }\end{array}$ \\
\hline $\begin{array}{l}\text { Chleb całoziarnowy pszenny* } \\
\text { Wholemeal wheat bread* }\end{array}$ & $6,0 \div 7,5^{*}$ & $\begin{array}{l}\text { Mufinki/otręby pszenne** } \\
\text { Muffins/wheat bran } * *\end{array}$ & $1,1 \div 4,2 / 8,2 * *$ \\
\hline $\begin{array}{l}\text { Chleb jasny pszenny } \\
\text { White wheat bread }\end{array}$ & $2,0 \div 2,9$ & $\begin{array}{l}\text { Ciasteczka /owsiane* } \\
\text { Cookies/oat } *\end{array}$ & $0,5 \div 3,2 / 16,1 *$ \\
\hline $\begin{array}{l}\text { Chleb chrupki pszenny } \\
\text { Wheat crispbread }\end{array}$ & 11,8 & $\begin{array}{l}\text { Krakersy/całoziarnowe* } \\
\text { Crackers/whole-grain* }\end{array}$ & $1,9 \div 3,6 / 10,9 *$ \\
\hline $\begin{array}{l}\text { Chleb całoziarnowy żytni* } \\
\text { Wholemeal rye bread* }\end{array}$ & $6,5 \div 12,0^{*}$ & $\begin{array}{l}\text { Makaron gotowany/całoziarnowy* } \\
\text { Cooked pasta/whole-grain* }\end{array}$ & $1,4 \div 1,8 / 4,6^{*}$ \\
\hline $\begin{array}{l}\text { Chleb jasny żytni } \\
\text { White rye bread }\end{array}$ & $5,8 \div 6,4$ & $\begin{array}{l}\text { Ryż biały gotowany } \\
\text { Cooked white rice }\end{array}$ & $0,4 \div 0,9$ \\
\hline $\begin{array}{l}\text { Chleb chrupki żytni } \\
\text { Wheat crispbread }\end{array}$ & 16,5 & $\begin{array}{l}\text { Ryż brązowy gotowany } \\
\text { Cooked brown rice }\end{array}$ & $1,6 \div 1,8$ \\
\hline $\begin{array}{l}\text { Chleb pumpernikiel } \\
\text { Pumpernickel bread }\end{array}$ & $6,5 \div 7,1$ & $\begin{array}{l}\text { Ryż dziki gotowany } \\
\text { Cooked wild rice }\end{array}$ & 1,8 \\
\hline $\begin{array}{l}\text { Chleb owsiany } \\
\text { Oat bread }\end{array}$ & $4,0 \div 4,9$ & $\begin{array}{l}\text { Kasza gryczana prażona gotowana } \\
\text { Cooked roasted buckwheat }\end{array}$ & 2,7 \\
\hline $\begin{array}{l}\text { Chleb bezglutenowy } \\
\text { Gluten-free bread }\end{array}$ & $3,5 \div 5,5$ & $\begin{array}{l}\text { Płatki kukurydziane } \\
\text { Cornflakes }\end{array}$ & $1,2 \div 3,4$ \\
\hline $\begin{array}{l}\text { Chleb ,pita"/całoziarnowy* } \\
\text { Pita bread/whole-grain * }\end{array}$ & $2,2 / 6,1 *$ & $\begin{array}{l}\text { Bulgur gotowany } \\
\text { Cooked bulgur }\end{array}$ & 4,5 \\
\hline $\begin{array}{l}\text { Bułki/całoziarnowe* } \\
\text { Rolls/whole-grains* }\end{array}$ & $1,3 \div 2,1 / 7,5^{*}$ & $\begin{array}{l}\text { Ziarno gotowe do spożycia** } \\
\text { Cereals ready to eat** }\end{array}$ & $0,4 \div 21,7 / 46,2 * *$ \\
\hline $\begin{array}{l}\text { Obwarzanki/całoziarnowe* } \\
\text { Bagels/whole-grains * }\end{array}$ & $2,3 \div 4,1 / 6,2 *$ & $\begin{array}{l}\text { Popcorn zwykły/pękający*** } \\
\text { Popcorn/low fat popping popcorn*** }\end{array}$ & $2,5 / 15,1 * * *$ \\
\hline $\begin{array}{l}\text { McD burger } \\
\text { Burger } \mathrm{McD}\end{array}$ & $1,0 \div 1,7$ & $\begin{array}{l}\text { Otręby pszenne } \\
\text { Wheat bran }\end{array}$ & 42,8 \\
\hline $\begin{array}{l}\text { Tortila/całoziarnowa* } \\
\text { Tortilla/whole-grains * }\end{array}$ & $2,4 \div 5,3 / 9,8^{*}$ & $\begin{array}{l}\text { Otręby owsiane } \\
\text { Oat bran }\end{array}$ & 15,4 \\
\hline $\begin{array}{l}\text { Pizze z Pizza Hut } \\
\text { Pizza Hut pizzas }\end{array}$ & $1,7 \div 2,4 / 4,3 *$ & $\begin{array}{l}\text { Otręby kukurydziane } \\
\text { Corn bran }\end{array}$ & 79,0 \\
\hline Musli / Muesli & $2,1 \div 3,1$ & Zarodki pszenne / Wheat germs & 13,2 \\
\hline
\end{tabular}

Objaśnienia / Explanatory notes:

* - produkty wytworzone z mąki całoziarnowej / products produced from whole-grain flour; ** - produkty wzbogacone dodatkiem otrąb / products enriched with bran; *** - kukurydza pękająca o obniżonej zawartości tłuszczu / low fat popping popcorn.

Źródło / Source: opracowanie własne na podstawie [27] / the author’s own study based on [27] 
zbożowych, obejmującej pieczywo zwykłe, specjalne i cukiernicze, ziarna gotowe do spożycia, otręby, całe ziarna, kasze i makarony gotowane, płatki, musli, przekąski, popcorn i produkty określane jako tzw. fast food - pizze i burgery [27]. Ilości DF w porównywanych produktach są bardzo zróżnicowane i zawierają się w przedziale od $0,4 \mathrm{~g} / 100 \mathrm{~g}$, np. w gotowanym białym ryżu, do 79,0 g/100 g w otrębach kukurydzianych. $\mathrm{Z}$ danych tych wynika podstawowy wniosek. Wszystkie nisko przetworzone produkty zbożowe otrzymane $\mathrm{z}$ całych ziaren oraz pochodzące $\mathrm{z}$ ich peryferyjnych warstw są wielokrotnie bogatsze w DF niż produkty wysoko przetworzone i oczyszczone w coraz bardziej złożonych procesach technologicznych. Na przykład produkty z jasnych mąk chlebowych i niechlebowych, jak np. chleb, bułki, pita, tortilla, krakersy czy makaron gotowany zawierają $2 \div 30$ razy mniej DF niż te same produkty wytworzone z mąki całoziarnowej czy z dodatkiem całych ziaren. Produktami najbardziej zasobnymi w ten składnik są otręby różnych rodzajów zbóż. Udowodniono, że DF jest nierównomiernie rozłożony w różnych częściach anatomicznych ziarniaków zbóż [10]. Najbogatsze w ten składnik są zewnętrzne warstwy ziarna, które obejmują tkanki okrywy owocowej, nasiennej oraz warstwy aleuronowej. Zawierają one ok. 2/3 ilości DF całego ziarna, a różnice pod względem zawartości tego składnika między peryferyjnymi a wewnętrznymi częściami ziarna sięgają nawet $70 \mathrm{~g} / 100 \mathrm{~g}$ [10]. Błonnik zawarty w okrywie owocowo-nasiennej prawie w całości stanowi frakcja IDF, podczas gdy w bielmie środkowym istotną jego część stanowi frakcja SDF. Najbardziej zasobne w SDF jest ziarno żyta i pszenżyta, następnie owsa i jęczmienia, natomiast najuboższe jest ziarno pszenicy. Podstawowymi ilościowo składnikami DF ziarna zbóż są arabinoksylany, $\beta$-glukany, fruktany, celuloza i lignina. W mniejszej ilości występują arabinogalaktany, oligosacharydy, skrobia oporna oraz kwasy fenolowe i uronowe związane NSP. Każdy z tych składników charakteryzuje się odmiennymi właściwościami funkcjonalnymi i zróżnicowanym zachowaniem w przewodzie pokarmowym, a zatem różnym oddziaływaniem na organizm człowieka.

W tab. 5. podano zawartość trzech głównych składników DF w czterech rodzajach podstawowych zbóż oraz w pszenżycie według różnych autorów $[1,3,7,8,11$, $12,21]$.

Dominującym ilościowo składnikiem DF w ziarnie żyta, pszenżyta i pszenicy są arabinoksylany, natomiast w ziarnie jęczmienia i owsa - $\beta$-glukany. Uwagę zwraca duża zawartość $\mathrm{w}$ pełni rozpuszczalnych $\mathrm{w}$ wodzie fruktanów w ziarnie żyta, co istotnie wpływa na zwiększenie zawartości ważnej żywieniowo frakcji SDF. Podobnie $\beta$-glukany zawarte w ziarnie jęczmienia i owsa są w przeważającej części rozpuszczalne i również zwiększają zawartość tej frakcji DF w produktach owsianych i jęczmiennych. Szczególną rolę fizjologiczną w organizmie człowieka przypisuje się $\beta$-glukanom i fruktanom oraz w mniejszym stopniu rozpuszczalnym LMW arabinoksylanom [29]. $\beta$-glukany są przede wszystkim odpowiedzialne za efekt hipoglikemiczny i hipocholesterolemiczny, 
Tabela 5. Zawartość składników błonnika pokarmowego w ziarnie zbóż

Table 5. Content of dietary fibre components in cereal grains

\begin{tabular}{|c|c|c|c|c|c|c|}
\hline \multirow{2}{*}{$\begin{array}{l}\text { Zboże (n) } \\
\text { Cereal (n) }\end{array}$} & \multicolumn{2}{|c|}{$\begin{array}{l}\text { Arabinoksylany } \\
\text { Arabinoxylans }\end{array}$} & \multicolumn{2}{|c|}{$\begin{array}{l}\beta \text {-glukany } \\
\beta \text {-glucans }\end{array}$} & \multicolumn{2}{|c|}{$\begin{array}{l}\text { Fruktany } \\
\text { Fructans }\end{array}$} \\
\hline & $\begin{array}{l}{[\% \text { s.m. }]} \\
{[\% \text { d.m. }]}\end{array}$ & $\begin{array}{l}\text { Lit. } \\
\text { Ref. }\end{array}$ & 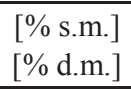 & $\begin{array}{l}\text { Lit. } \\
\text { Ref. }\end{array}$ & $\begin{array}{l}{[\% \text { s.m. }]} \\
{[\% \text { d.m. }]}\end{array}$ & $\begin{array}{l}\text { Lit. } \\
\text { Ref. }\end{array}$ \\
\hline $\begin{array}{l}\text { Pszenica }\left(\mathrm{n}=26 / 10^{*}\right) \\
\text { Wheat }\left(\mathrm{n}=26 / 10^{*}\right)\end{array}$ & $4,4 \div 6,9$ & [8] & $0,5 \div 1,0$ & [8] & $0,9 \div 1,6^{*}$ & {$[7]^{*}$} \\
\hline $\begin{array}{l}\text { Żyto }(n=45) \\
\text { Rye }(n=45)\end{array}$ & $8,0 \div 12,1$ & {$[3]$} & $1,6 \div 2,2$ & [3] & $4,6 \div 6,3$ & {$[3]$} \\
\hline $\begin{array}{l}\text { Jęczmień }\left(\mathrm{n}=3 / 39^{*}\right) \\
\text { Barley }\left(\mathrm{n}=3 / 39^{*}\right)\end{array}$ & $4,9 \div 5,2$ & [12] & $2,4 \div 8,3$ & {$[11]^{*}$} & 1,6 & {$[11]^{*}$} \\
\hline $\begin{array}{l}\text { Owies }\left(\mathrm{n}=3^{*} / 121^{* *}\right) \\
\text { Oat }\left(\mathrm{n}=3 * / 121^{* *}\right)\end{array}$ & $1,6 \div 1,9$ & {$[3]^{*}$} & $1,8 \div 5,5$ & {$[1]^{* *}$} & 0,1 & {$[1]^{* *}$} \\
\hline $\begin{array}{l}\text { Pszenżyto }(\mathrm{n}=16) \\
\text { Triticale }(\mathrm{n}=16)\end{array}$ & $5,9 \div 7,5$ & [21] & $0,5 \div 1,0$ & {$[21]$} & $1,6 \div 2,9$ & [21] \\
\hline
\end{tabular}

Objaśnienia / Explanatory notes:

*/** - liczba próbek według różnych autorów / number of samples according to different authors

podczas gdy fruktany i frukto-oligosacharydy, zwłaszcza krótkołańcuchowe, oraz niektóre LMW frakcje arabinoksylanów i $\beta$-glukanów - za efekt probiotyczny [29]. Naukowo udowodniono, że dla osiągnięcia efektu hipoglikemicznego i hipocholesterolemicznego minimalna dzienna dawka $\beta$-glukanów powinna wynosić $3 \mathrm{~g} / \mathrm{dzień} \mathrm{[6].} \mathrm{Nie}$ unormowano natomiast minimalnego dobowego spożycia fruktanów, jednak dla uzyskania oczekiwanego efektu probiotycznego najczęściej wymienia się dawki ok. $15 \mathrm{~g} /$ dzień [17].

\section{Podsumowanie}

W ostatnich latach daje się zauważyć wyraźny postęp w badaniach nad błonnikiem pokarmowym (DF) oraz w pracach legislacyjnych dotyczących zaleceń odnoszących się do zdrowego odżywiania. Do najważniejszych osiągnięć należy ujednolicenie definicji DF zgodnej z aktualnym stanem wiedzy oraz opracowanie nowych metod referencyjnych ilościowego oznaczania tego składnika, dostosowanych do aktualnie obowiązującej definicji. W Polsce należałoby podjąć działania zmierzające do zastąpienia 20-letniej normy ilościowego oznaczania DF nową procedurą, która odpowiadałaby współczesnym wymogom. Wskazane byłoby ponadto sprecyzowanie przez lekarzy i ekspertów żywieniowych wielkości dawek dziennego spożycia tego składnika, z uwzględnieniem płci oraz różnych przedziałów wieku. Na podstawie najnowszych danych wykazano, że produkty zbożowe stanowią podstawowe źródło DF w codziennej diecie Polaków. W celu utrzymania czołowej pozycji produktów zbożowych pożą- 
dane byłoby opracowanie nowych i atrakcyjnych sensorycznie produktów całoziarnowych, jak i wzbogaconych wysokobłonnikowymi dodatkami pochodzącymi z zewnętrznych części ziarna. Dotyczy to zwłaszcza produktów żytnich, owsianych i jęczmiennych bogatych w rozpuszczalne składniki błonnika. Równolegle należy prowadzić intensywne działania edukacyjne, zwłaszcza wśród dzieci i młodzieży, promujące spożycie wysokobłonnikowych produktów zbożowych ze szczególnym uwzględnieniem ich prozdrowotnych funkcji oraz roli w profilaktyce przewlekłych chorób niezakaźnych (NCDs).

\section{Literatura}

[1] Åman P.: The variation in chemical composition of Swedish oats. Acta Agriculturae Scandinavica 1987, 3 (37), 347-352.

[2] Bienkiewicz M., Bator E., Bonkowska M: Błonnik pokarmowy i jego znacznie w profilaktyce zdrowotnej. Problemy Hig. Epidol., 2015, 1 (96), 57-63.

[3] Boskov Hansen H., Rasmussen C.V., Bach Knudsen K.E., Hansen A.: Effects of genotype and harvest year on contents and composition of dietary fibre in rye (Secale cereale L) grain. J. Sci. Food Agric., 2003, 1 (83), 76-85.

[4] Burkitt D.P., Trowell H.C.: Refined Carbohydrate Foods and Disease: Some Implications of Dietary Fibre. Academic Press, London 1975.

[5] Codex Alimentarius Commission. Procedural Manual. 20 $0^{\text {th }}$ ed. FAO, Rome 2011.

[6] EFSA: Scientific opinion - scientific opinion on dietary reference values for carbohydrates and dietary fibre. EFSA J., 2010, 8, 1462-1477.

[7] Fretzdorff B., Welge N.: Fructan- und Raffinosegehalte im Vollkorn einiger Getreidearte und Pseudo-Ceralien. Getreide, Mehl und Brot, 2003, 1 (57), 3-8.

[8] Gebruers K., Dornez E., Bedõ Z., Rakszegi M., Frás A., Boros D., Courtin C.M., Delcour J.A.: Environment and genotype effects on the content of dietary fiber and its components in wheat in the HEALTHGRAIN diversity screen. J. Agric. Food Chem., 2010, 17 (58), 9353-9361.

[9] Górecka D., Janus P., Borysiak-Marzec P., Dziedzic K.: Analiza spożycia błonnika pokarmowego i jego frakcji w Polsce w ostatnim dziesięcioleciu w oparciu o dane GUS. Problemy Hig. Epidol., 2011, 4 (92), 705-708.

[10] Hemery Y., Rouau X., Lullien-Pellerin V., Barron C., Abecassis J.: Dry process to develop wheat fraction and products with enhanced nutritional quality. J. Cereal Sci., 2007, 3 (46), 327-347.

[11] Holtekjølen A.K., Uhlen A.K., Bråthen E., Sahlstrøm S., Knutsen, S.H.: Contents of starch and nonstarch polysaccharides in barley varieties of different origin. Food Chem., 2006, 3 (94), 348-358.

[12] Izydorczyk M.S., McMillan T., Bazin S., KletkeB., Dushnicky L., Dexter J., Chepurna A., Rossnagel B.: Milling of Canadian oats and barley for functional food ingredients: Oat bran and barley fibre-rich fractions. Can. J. Plant Sci., 2014, 3 (94), 573-586.

[13] Jacobs D.R., Meyer K.A., Kushi L.H., Folsom A.R.: Is whole-grain intake associated with reduced total and cause-specific death rates in older women? The Iowa Women's Health Study. Am. J. Public Health, 1999, 89, 322-329.

[14] Jones M.J.: CODEX-aligned dietary fiber definitions help to bridge the "fiber gap". Nutr. J., 2014, 1 (13), 34-43.

[15] Kowalczyk M., Zegan M., Michota-Katulska E.: Wiedza na temat prozdrowotnej roli błonnika pokarmowego wśród studentów uczelni medycznych i pozamedycznych. Bromatol. Chemia Toksyl., 2017, 2 (50), 99-105.

[16] Laskowski W.: Wartość odżywcza diety Polaków i jej zmiany. W: Współczesne kierunki działań prozdrowotnych. Red. A. Wolska-Adamczyk. Wyd. WSIiZ, Warszawa 2017, ss. 57-72. 
[17] Maziarz M.P.: Role of fructans and resistant starch in diabetes care. Diabetes Spectrum, 2013, 1 (26), 35-39.

[18] McIntosh G.H., Noakes M., Royle P.J., Foster P.R.: Whole-grain rye and wheat foods and markers of bowel health in overweight middle-aged men. Am. J. Clin. Nutr., 2003, 4 (77), 967-974.

[19] Paczkowska M., Kunachowicz H., Rutkowska U.: Jakość zdrowotna krajowych racji pokarmowych badania analityczne i ocena teoretyczna. Cz. IV. Błonnik pokarmowy. Żyw. Człow. Metab, 2000, 27, 9-12.

[20] PN-A-79011-15:1998. Koncentraty spożywcze. Metody badań. Oznaczanie zawartości błonnika pokarmowego.

[21] Rakha A., Åman P., Andersson R.: Dietary fibre in triticale grain: Variation in content, composition, and molecular weight distribution of extractable components. J. Cereal Sci., 2011, 3 (54), 324-331.

[22] Rimm E.B., Asherio A., Giovannucci E., Spiegelman D., Stampfer M.J., Willet W.C.: Vegetable, fruit and cereal fiber intake and risk of coronary heart disease among men. J. Am. Medical Association, 1996, 275, 447-451.

[23] Mały rocznik statystyczny Polski / Rocznik Statystyczny Rolnictwa. Główny Urząd Statystyczny, Rok LX, Warszawa 2017.

[24] Slavin J.L., Jacobs D., Marquart L., Wiemer K.: The role of whole grains in disease prevention. J. Am. Dietetic Association, 2001, 7 (101), 780-785.

[25] Slavin J.L.: Why whole grains protective: Biological mechanisms. Proc. Nutr. Soc., 2003, 1 (62), 129-134.

[26] Trowell H.: Crude fibre, dietary fibre and atherosclerosis. Atherosclerosis, 1972, 2 (16), 138-140.

[27] USDA: National Nutrient Database 28 SR for Standard Reference. United States Department of Agriculture, Washington 2018.

[28] Wojtyniak B., Goryński P., Moskalewicz B.: Sytuacja zdrowotna ludności Polski i jej uwarunkowania. Narodowy Instytut Zdrowia Publicznego - PZH, Warszawa 2012, s. 339.

[29] Zhang G., Hamaker B.R.: Cereal carbohydrates and colon health. Cereal Chem., 2010, 4 (87), 331341.

[30] Zielinski G., DeVries J.W., Craig S.A., Bridges A.R.: Dietary fiber in CODEX Alimentarius: Current status and ongoing discussions. Cereal Foods World, 2013, 3 (58), 148-152.

\section{CEREAL GRAINS AND CEREAL PRODUCTS AS SOURCES OF DIETARY FIBRE}

\section{S u m m a r y}

Based on the interdisciplinary research, a close relationship was demonstrated between the dietary fibre intake and the number of new cases of non-communicable diseases. In the research study, there were discussed a dietary fibre definition and those dietary fibre quantifying methods, which were concordant with the currently applicable concept of fibre. The most recent data were presented with respect to the recommended dietary fibre intake as were the data on what was the level of consumption, by the average Pole, of fibre and food products containing that component. It is confirmed by the statistical data derived from the Central Statistical Office in Poland (referred to as GUS) and by the latest data derived from the USDA National Nutrient Database 28 SR on the contents of nutrients in 7,999 food products that in Poland cereal products constitute the main source of dietary fibre. It was shown that in 2016, in our country the average daily consumption of DF was $15.4 \mathrm{~g} /$ persons and about $43 \%$ of the DF daily intake came from cereal products, of which two-thirds were bread products. Moreover, the dietary fibre content in various types of cereals was compared with that in 1,494 cereal products. The basket of those products includes many new items, which, now, are more and more eaten by consumers in Poland and which are not taken into account in the national reference literature pertaining to nutrition. The data analysis showed that all the low-processed cereal products produced from the whole grains or with the whole grains added were 
many times richer in dietary fibre than those highly-refined and cleaned during technological processes as were the products originating from peripheral layers of kernel.

Key words: dietary fibre, definition, determination methods, cereal grains and cereal products, consumption of fibre and cereal products in Poland 